Tropical Journal of Pharmaceutical Research November 2016; 15 (11): 2445-2449

ISSN: $1596-5996$ (print); 1596-9827 (electronic)

(C) Pharmacotherapy Group, Faculty of Pharmacy, University of Benin, Benin City, 300001 Nigeria.

All rights reserved.

Available online at http://www.tjpr.org

Original Research Article

http://dx.doi.org/10.4314/tjpr.v15i11.20

\title{
Effect of Turkish pollen and propolis extracts on caspase-3 activity in myeloid cancer cell lines
}

\author{
Meltem Uçar ${ }^{1}$, Orhan Değer ${ }^{2}$, Asuman Yiğit Gerigelmez ${ }^{2}$, Sevil Cengiz ${ }^{3}$, Yaşam \\ Barlak $^{4}$, Ercüment Ovalı ${ }^{5}$ \\ ${ }^{1}$ Faculty of Health Science, European University of Lefke, Lefke, 99728, Turkish Republic of Northern Cyprus, ${ }^{2}$ Department of \\ Medical Biochemistry, Faculty of Medicine , Karadeniz Technical University ,Trabzon, ${ }^{3}$ Department of Emergency and Disaster \\ Management, High School of Health, University of Gumushane, Gumushane, ${ }^{4}$ Karadeniz Advanced Technology Research and \\ Application Centre (KITAM), Ondokuz Mayıs University, Samsun, ${ }^{5}$ Acıbadem Labcell, Üsküdar, İstanbul, Turkey
}

${ }^{*}$ For correspondence: Email: mucar@eul.edu.tr; Tel: +90392 660-2554; Fax: +90392 6602553

\begin{abstract}
Purpose: To investigate the apoptosis-inducing capacity of dimethyl sulfoxide (DMSO) extracts of bee pollen and propolis in HL-60 Myeloid Cancer Cell Lines.

Methods: DMSO extracts of pollen and propolis were incubated separately with HL-60 cells, and caspase-3 activity evaluated. In order to determine the cell cycle characteristics of HL-60 cells with and without extracts of pollen and propolis, the cells were analysed using flow cytometry.

Results: The DMSO extract of propolis $(0.5 \mathrm{mg} / \mathrm{mL})$ increased apoptosis from undetectable levels to $60.1 \%$, while maintaining cell viability. The DMSO extract of pollen $(2 \mathrm{mg} / \mathrm{ml})$ increased apoptosis from undetectable levels to $52.2 \%$ while decreasing cell viability by $62 \%$. Caspase-3 activity in HL-60 cells incubated with DMSO extracts of pollen and propolis were 3.6- to 12-fold higher than in controls.

Conclusion: Turkish pollen and propolis individually increase apoptosis and the activity of caspase-3 in HL-60 cells. This finding indicates that bee products may have beneficial effects in the treatment of cancer.
\end{abstract}

Keywords: Pollen, Propolis, Apoptosis, Caspase-3, Myeloid Cancer

Tropical Journal of Pharmaceutical Research is indexed by Science Citation Index (SciSearch), Scopus, International Pharmaceutical Abstract, Chemical Abstracts, Embase, Index Copernicus, EBSCO, African Index Medicus, JournalSeek, Journal Citation Reports/Science Edition, Directory of Open Access Journals (DOAJ), African Journal Online, Bioline International, Open-J-Gate and Pharmacy Abstracts

\section{INTRODUCTION}

Pollen is produced by bees after collecting millions of pollen and they use it as a food [1]. Propolis is collected from trees and some plants which have resin. Bees use propolis for repairing their hive, and also use it as antiseptic against invaders [2]. Bee pollen involves polyphenolic compounds, flavonoids, proteins, essential free amino acids for humans, carbohydrates, vitamins, minerals depending on the geographic area and climate from which they were collected $[1,3]$. Propolis generally is composed of $50 \%$ resin and vegetable balsam, $30 \%$ wax, $10 \%$ essential and aromatic oils, $5 \%$ pollen and $5 \%$ various other substances, including organic debris. Hundreds of chemical compounds have been identified from propolis.

The main chemical classes present in propolis are flavonoids, phenolics, and various aromatic compounds but there is a standardization problem [2]. Bee pollen has anti-atherosclerotic, anti-neoplastic, antimicrobial, antimutagenic and antioxidant activities [4]. Propolis also has antibacterial, anti-viral, anti-fungal activities and immune activating and cytotoxic effect on cancer cells, anti-inflammatory, anaesthetic and 
antioxidant activities [2]. Antioxidant activities of both pollen and propolis originate from their polyphenolic compounds and flavonoids. Both pollen and propolis contain considerable amounts of poyphenolic substances such as quercetin, caffeic acid and caffeic acid phenethyl ester (CAPE), pinocembrin, galangin, etc. which may act as potent antioxidants $[1,4,5]$.

Apoptosis is programmed cell death and occurs when the cell life cycle ends or various apoptosis triggers such as radiation, hazardous chemicals, drugs damage the cell [6,7]. Caspase-3 activation has an effector role in both the receptor and mitochondria mediated apoptosis [8]. Caspase cascade and cell death can be initiated by caspase-3 activation [9].

DMSO extracts of propolis and pollen at different concentrations were used to investigate antitumor and apoptosis-inducing activity in myeloid $\mathrm{HL}-60$ cell line with lymphoid cell culture as a control. Flow-cytometry and spectrophotometric caspase-3 activity were used to determine the apoptosis-inducing activity.

\section{EXPERIMENTAL}

\section{Propolis and pollen}

Propolis and pollen samples were obtained from honey-bees (Apis mellifera L.) in the region of Yomra, Trabzon, Turkey rich in Picea orientalis, Fagus orientalis, Castanea sativa, Rhodendron ponticum, Rhododendron luteum and Rubus caucasicus [10]. They were provided by Trabzon Agricultural Development Cooperative.

\section{Preparation of DMSO extracts of pollen and propolis}

Natural propolis samples were pulverized by grinding (Retsch, ZM 200). A $5 \mathrm{~g}$ pollen and ground propolis samples were dissolved in $5 \mathrm{~mL}$ of DMSO $(100 \% \mathrm{w} / \mathrm{v})$ by continuous mixing for 5 $\mathrm{h}$, then kept at $37^{\circ} \mathrm{C}$ in water bath overnight. Extracts of $4 \mathrm{~mL}(1000 \mathrm{mg} / \mathrm{mL})$ obtained by centrifuging at $800 \mathrm{~g}$ for $15 \mathrm{~min}$ were filtered and final volumes were made up to $10 \mathrm{~mL}$ with deionised water. Filtration procedure was repeated and the final extract was adjusted to 10 $\mathrm{mL}$ by deionised water to give a stock concentration of pollen and propolis extracts of $240 \mathrm{mg} / \mathrm{mL}$. Working solutions at final concentrations of $0,0.125,0.25,0.5,1$ and 2 $\mathrm{mg} / \mathrm{mL}$ were prepared in phosphate buffered saline (PBS).
HL-60 myeloid cancer cell line and MNC cell isolation

HL-60 cell line (Hematology Laboratory, Faculty of Medicine, KTU, (American Type Culture Collection) was maintained as recommended by the manufacturer, while mononuclear cells (MNC) were obtained from $50 \mathrm{~mL}$ of heparinized peripheral blood supplied by the Blood Bank with Ficoll density gradient (density 1000 lymphoprep Nycomed Pharma, Oslo) and subsequent basic cell culture procedures using RPMI 1640 medium.

\section{Cell culture and incubation of pollen and propolis extracts}

MNC and HL-60 myeloid cancer cells were incubated in propolis and pollen extracts of final concentrations of $0,0.125,0.25,0.5,1$ and 2 $\mathrm{mg} / \mathrm{mL}$ in RPMl 1640 containing $10 \%$ fetal calf serum, $1 \%$ penicillin and streptomycin under 5 $\% \mathrm{CO}_{2}$ pressure at $37{ }^{\circ} \mathrm{C}$ for $72 \mathrm{~h}$.

\section{Reagents}

All reagents used were of analytical grade. DMSO was purchased from Sigma, Germany.

\section{Cell viability}

Pellets of cells were washed twice with PBS, then suspended in $25 \mu \mathrm{L}$ PBS, then $1 \mu \mathrm{L}$ of a mixture of fluorescent dyes containing $100 \mu \mathrm{g} / \mathrm{mL}$ acridine orange and $100 \mu \mathrm{g} / \mathrm{mL}$ ethidium bromide (AO/EB) was added to the cells and mixed gently. A drop of the mixture was placed on a microscope slide and covered with a coverslip. The cells were visualized under a fluorescent microscope, using excitation wavelength at 510 $\mathrm{nm}$ [11]. All experiments were done in duplicate.

\section{Determination of apoptosis by flow- cytometric fluorescence analysis}

The DNA content of the stained nuclei was analyzed by flow cytometry (Coulter Epics Elite ESP). The distribution of DNA content was expressed as $\mathrm{G} 1, \mathrm{~S}$, and $\mathrm{G} 2 / \mathrm{M}$ phases. The cells with DNA content less than G1 were distributed in pre-G1 (hypodiploid cells) and expressed as the apoptotic phase [12]. All experiments were performed in duplicates.

\section{In vitro caspase-3 assay}

The activity of CPP32/caspase-3 was determined in cell extracts using a colorimetric protease assay kit (Biosource International USA, Catalog no: CPP32-KHZ 0022). The cells were collected 
and lysed with cell lysis buffer. Cell lysate was incubated with reaction buffer containing $5 \mu \mathrm{L}$ of peptide substrate (DEVD-pNA) for $2 \mathrm{~h}$ at $37{ }^{\circ} \mathrm{C}$. The cleavage of colorimetric peptide substrate was monitored by pNA ( $p$-nitroanilide) liberation using a microtiter plate reader at $405 \mathrm{~nm}$ with Spectra Fluor Plus, Tecan A 5082 spectrophotometer. The activity was expressed as fold change of absorbance value over that at 0 concentration. All experiments were performed in duplicates.

\section{Statistical analysis}

Data are expressed as mean \pm standard deviation (SD) for variables. Compatibility with normal distribution was determined using Kolmogorov-Smirnov test. One-way ANOVA was used to compare differences among the groups. Comparison of two groups was done by Student's t-test.

\section{RESULTS}

As shown in Table 1, significant differences were found among concentration groups. In particular, propolis extracts of 2 and $1 \mathrm{mg} / \mathrm{mL}$ had toxic effect on HL-60 cancer cells. Also, those concentrations did not lead to any differentiation and changed morphological appearances of the cells. However, $0.5,0.25,0.125 \mathrm{mg} / \mathrm{mL}$ propolis extracts increased HL-60 cancer cell number in the $S$ phase and also increased mitotic activity. Cell viability was lower in cancer cells treated with 2 and $1 \mathrm{mg} / \mathrm{mL}$ propolis extracts (<60\%). However, cell viability was higher (> $75 \%)$ in cancer cells treated with $0.125 \mathrm{mg} / \mathrm{mL}$ propolis extracts. As shown in Table 1 propolis extracts increased caspase-3 activity variously depending on concentration. Optimal increase occurred with 0.25 to $0.5 \mathrm{mg} / \mathrm{ml}$ extract. At these concentrations, apoptosis was high (45.1 to 60.1
$\%$ ); differentiation was also high (10 to $15 \%$ ). However, the increase in caspase-3 activity in MNC cells was not as high.

As shown in Table 2, significant differences were found among concentration groups. Pollen DMSO extract $(2 \mathrm{mg} / \mathrm{mL})$ had higher apoptotic activity (52.2 \%) in HL-60 cancer cells than control and other groups. The highest concentration ( $2 \mathrm{mg} / \mathrm{mL}$ pollen DMSO extracts) also had increased cell number in which $S$ and $\mathrm{G}_{2} \mathrm{M}$ phase were high. Caspase-3 activity also was higher at this concentration than others. Therefore, only pollen extract of $2 \mathrm{mg} / \mathrm{mL}$ seems to exert apoptotic activity. But, pollen extracts had no differentiation activity. In addition, DMSO pollen extract had a 1.75 fold increase in caspase- 3 activity in MNC cells (data not shown).

\section{DISCUSSION}

There are a lot of investigations about biological, biochemical, physiological, pharmaceutical and medicinal properties of polyphenolic compounds and flavonoids. There are also many studies about free radical scavenging activity and multiple biological activities of pollen and propolis including anti-inflammatory, immunomodulatory, anticarcinogenic and antioxidative or radical scavenging activity. All those studies suggested that pollen and propolis have these properties because of polyphenolic compounds and flavonoids they contain. Analysis of phenolic compounds and flavonoids of Turkish propolis was previously carried out in our laboratory. According to HPLC analysis, the main flavonoids found include galangin, naringenin, chrysin, kaempferol, quercetin and cinnamic acid derivatives for DMSO extracts and, caffeic and caffeoyl quinic acids for water extracts [13].

Table 1: Effect of concentration of propolis extracts in HL-60 cell lines on cell cycle, apoptosis and cell differential

\begin{tabular}{|c|c|c|c|c|c|c|}
\hline \multirow[t]{2}{*}{ Parameter } & \multicolumn{6}{|c|}{ Extract $(\mathrm{mg} / \mathrm{mL})$} \\
\hline & 2 & 1 & 0.5 & 0.25 & 0.125 & 0 \\
\hline $\mathrm{G}_{0} / \mathrm{G}_{1}(\%)^{*}$ & $80.0 \pm 0,14$ & $79.2 \pm 0.28$ & $28.0 \pm 0.21$ & $32.3 \pm 0.28$ & $39.3 \pm 0.28$ & $48.9 \pm 0.21$ \\
\hline $\mathrm{S}(\%)^{*}$ & $13.0 \pm 0.07$ & $13.0 \pm 0.07$ & $42.1 \pm 0.21$ & $64.0 \pm 0.57$ & $57.3 \pm 0.28$ & $50.3 \pm 0.28$ \\
\hline $\mathrm{G}_{2} \mathrm{M}(\%)^{*}$ & $1.75 \pm 0.07$ & $8.0 \pm 0.07$ & $30.3 \pm 0.42$ & $3.2 \pm 0.07$ & $1.3 \pm 0.07$ & $1.2 \pm 0.07$ \\
\hline $\begin{array}{l}\text { Apoptosis } \\
(\%)^{*}\end{array}$ & $19.7 \pm 0.07$ & $44.7 \pm 0.21$ & $60.0 \pm 0.14$ & $45.6 \pm 0.64$ & - & - \\
\hline $\begin{array}{l}\text { Differential } \\
(\%)\end{array}$ & 0 & 0 & 10 & 15 & 3 & 0 \\
\hline Viability (\%) & $<60$ & $<60$ & $>60$ & $>60$ & $>75$ & $>75$ \\
\hline $\begin{array}{l}\text { Increase in } \\
\text { caspase-3 } \\
\text { activity** }^{* *}\end{array}$ & $0.9 \pm 0.01$ & $3.2 \pm 0.06$ & $5.4 \pm 0.01$ & $11.9 \pm 0.11$ & $2.1 \pm 0.04$ & $1.0 \pm 0.00$ \\
\hline
\end{tabular}


Table 2: Effect of concentration of pollen extract in HL-60 cell line on cell cycle, apoptosis and cell differentiation

\begin{tabular}{lcccccc}
\hline Parameter & \multicolumn{7}{c}{ Extract $\mathbf{( m g / m L})$} \\
\cline { 2 - 7 } & $\mathbf{2}$ & $\mathbf{1}$ & $\mathbf{0 . 5}$ & $\mathbf{0 . 2 5}$ & $\mathbf{0 . 1 2 5}$ & $\mathbf{0}$ \\
\hline $\mathrm{G}_{0} / \mathrm{G}_{1}(\%)^{*}$ & $37.2 \pm 0.21$ & $24.4 \pm 0.21$ & $42.3 \pm 0.21$ & $43.9 \pm 0.21$ & $45.7 \pm 0.50$ & $47.0 \pm 0.07$ \\
$\mathrm{~S}(\%)^{*}$ & $54.6 \pm 0.35$ & $69.4 \pm 0.85$ & $56.2 \pm 0.21$ & $55.0 \pm 0.07$ & $53.6 \pm 0.21$ & $49.2 \pm 0.14$ \\
$\mathrm{G}_{2} \mathrm{M}(\%)^{*}$ & $8.0 \pm 0.07$ & $6.9 \pm 0.14$ & $1.7 \pm 0.07$ & $1.3 \pm 0.07$ & $1.1 \pm 0.07$ & $3.6 \pm 0.14$ \\
$\begin{array}{l}\text { Apoptosis } \\
(\%)^{* *}\end{array}$ & $52.1 \pm 0.14$ & $1.0 \pm 0.14$ & - & - & - & - \\
$\begin{array}{l}\text { Differential } \\
(\%)\end{array}$ & 0 & 0 & 0 & 0 & 0 & 0 \\
Viability (\%) & 62 & 80 & 80 & 80 & 89 & 90 \\
$\begin{array}{l}\text { Fold Increase } \\
\text { of Caspase-3 }\end{array}$ & $3.7 \pm 0.04$ & $2.2 \pm 0.04$ & $1.8 \pm 0.02$ & $1.5 \pm 0.04$ & $1.2 \pm 0.02$ & $1.0 \pm 0.00$ \\
Activity*** & & & & & &
\end{tabular}

$\left(\mathrm{G}_{0}=\mathrm{Gap}_{0} /\right.$ Resting phase, $\mathrm{G}_{1}=\mathrm{Gap}_{1}, \mathrm{~S}=$ Synthesis and $\mathrm{G}_{2}=\mathrm{Gap}_{2}$ are interphase and $\mathrm{M}=$ Mitosis period of cell cycle); ${ }^{*} p<0.001 ;{ }^{* *} p<0.001 ;{ }^{* * *}$ fold-increase

The main finding in the present study was that DMSO extracts of pollen and propolis at different concentrations promoted apoptosis in HL-60 cells by activating caspase-3. DMSO extract of propolis $(0.5 \mathrm{mg} / \mathrm{mL})$ increased apoptosis from undetectable to $60.1 \%$, while maintaining cell viability. But 1 and $2 \mathrm{mg} / \mathrm{mL}$ concentration of DMSO extract of propolis had cytotoxic effect on HL-60 cells and decreased cell viability to $<60$ percent. However, $0.5,0.25$ and $0.125 \mathrm{mg} / \mathrm{mL}$ concentration of DMSO extract of propolis caused differentiation in HL-60 cells. On the other hand all concentrations of DMSO extracts of propolis increased caspase- 3 activity in HL-60 cells when compared with control that is $0 \mathrm{mg} / \mathrm{mL}$ concentration. Fold-increase of caspase-3 activity was changed from 0.88 to 12.00 in HL-60 cells. Furthermore, only 2 and $1 \mathrm{mg} / \mathrm{ml}$ concentration of DMSO extract of pollen induced apoptosis in HL-60 cells from non-detectable level to 52.2 and $0.9 \%$ respectively. Caspase-3 activity in cells which were incubated with DMSO extracts of pollen was found to be concentration dependent. It was changed from 1.25- to 3.65fold.

Many chemopreventive agents act through the induction of apoptosis as a mechanism of antitumorigenesis. Eroğlu et al [14] and Gunduz et al [15] suggested that Turkish propolis can decrease cell division in tissue cultures of bladder cancer and may show antitumoral and apoptotic effect on leukemia cells. Chen et al [16] investigated the mechanism of CAPE-induced apoptosis in human leukemic HL-60 cells. It was found that CAPE entered HL-60 cells very quickly and inhibited their survival depending on the concentration and time. They also observed DNA fragmentation and morphological changes typical of apoptosis in the cells. CAPE caused rapid activation of caspase-3, down-regulation of Bcl-2 expression and up-regulation of Bax expression in HL-60 cells [16].
Jin et al [17] investigated the mechanism of CAPE-induced apoptosis in $U 937$ cells. They showed that CAPE decreased cell viability in dose-dependent and time dependent manner, DNA fragmentation and nuclear condensation in cancer cells and apoptotic action accompanied by release of cytochrome $\mathrm{c}$, reduction of $\mathrm{Bcl}-2$ expression, increase of Bax expression [17].

Woo et al [18] also used a different component of propolis, chrysin in U937 cells and they showed that chrysin activated caspase- 3 and inactivated Akt [18]. Propolin A, propolin B and propolin C, components of propolis, were used by Chen et al $[19,20]$ in human melanoma A2058, HL-60, MCF-7, human neuroblastoma IMR-32, C6, murine melanoma B16F10, Hep.G2, human hepatocellular carcinoma Hep.3B and HT-29 cells. They showed that propolin A, propolin B and propolin $\mathrm{C}$ are cytotoxic to cancer cells. They also observed that those components induce apoptosis by decreasing procaspase-8, Bid, procaspase-3, DFF45 and PARP(poly ADP ribose polymerase) depending on the time and dose $[19,20]$.

In the present study, propolis or pollen extracts alone were preferred to their polyphenolic or flavonoid components such as CAPE, galangin, pinocembrin etc. We suggest that those extracts may exert their anti-tumoral activities by boosting the immune system. Also Premratanachai and Chanchao [21] suggested that the mechanism of action of bee products in inhibiting tumor growth in vitro and in vivo is mediated via apoptosis, necrosis and lysis of tumor cells [21].

\section{CONCLUSION}

Both DMSO extracts of Turkish propolis and pollen may induce apoptosis in high concentrations in cancer cells. Further studies 
are required to elucidate the mechanism of action in higher concentrations.

\section{DECLARATIONS}

\section{Acknowledgement}

This research was supported by Foundation of Karadeniz Technical University (Project Numbers: 114.001.14), Trabzon, Turkey.

\section{Conflict of Interest}

No conflict of interest associated with this work.

\section{Contribution of Authors}

The authors declare that this work was done by the authors named in this article and all liabilities pertaining to claims relating to the content of this article will be borne by them.

\section{Open Access}

This is an Open Access article distributed under the terms of the Creative Commons Attribution License, which permits unrestricted use, distribution, and reproduction in any medium, provided the original work is properly credited.

\section{REFERENCES}

1. Schmidt JO. Bee Products Chemical Composition and Application. Bee Products Properties, Applications, and Apitherapy. In: Mizrahi A, Lensky Y, Eds. New York, Plenum Press, 1997, pp 15-26.

2. Burdock GA. Review of the biological properties and toxicity of bee propolis (Propolis). Food Chem Toxicol 1998; 36: 347-363.

3. Sattler JAG, de Melo ILP, Granato D, Araujo E, de Freitas AS, Barth OM, Sattler A, de AlmediaMuradian LB. Impact of origin on bioactive compounds and nutritional composition of bee pollen from southern Brazil: A screening study. Food Res Int 2015; 77: 82-91.

4. Pascoal A, Rodrigues S, Teixeira A, Feas X, Estevinho LM. Biological activities of commercial bee pollens: Antimicrobial, antimutagenic, antioxidant and antiinflammatory. Food Chem Toxicol 2014; 63: 233-239.

5. Zhou J, Qi Y, Ritho J, Zhang Y, Zheng X, Wu L, Li Y, Sun $L$. Flavonoid glycosides as floral origin markers to discriminate of unifloral bee pollen by LC-MS/MS. Food Control 2015; 57: 54-61.

6. Hotchkiss RS, Strasser A, McDunn JE, Swanson PE. Cell Death in Disease: Mechanisms and Emerging Therapeutic Concepts. N Engl J Med 2009; 361(16): 1570-1583.
7. Li J, Yin Q, Wu H. Structural Basis of Signal Transduction in the TNF Receptor Superfamily. Adv Immunol 2013; 119: 135-153.

8. Shalini S, Dorstyn L, Dawar S, Kumar S. Old, new and emerging functions of caspases. Cell Death Differ 2015; 22: 526-539.

9. Ho PK, Hawkins CJ. Mammalian Initiator apoptoic caspases. FEBS J 2005; 272(21): 5436-5453.

10. Davis PH. Flora of Turkey and the East Aegean Islands, Edinburgh University Press, Edinburgh, 1965-85; Vols. 1-9.

11. Tan L, Jia H, Liu R, Wu J, Han H, Zuo Y, Yang S, Huang W. Inhibition of NF-қB in fusogenic membrane glycoprotein causing HL-60 cell death: Implications for acute myeloid leukemia. Cancer Lett 2009; 273: 114121.

12. Jaroszeski MJ, Heller R. Analysis of Apoptosis by Flow Cytometry. Flow Cytometry Protocols In: Gorczyca W, Melamed MR, Darzynkiewicz Z, Eds. New Jersey, Humana Press, 1998; pp. 217-238.

13. Cakiroglu TN. Investigation of Solubility of Turkish Propolis in Different Solvents. Master Thesis, Karadeniz Technical University, Institute of Health Sciences, Trabzon, Turkey, 2010.

14. Eroglu HE, Ozkul Y, Tatısen A, Silici S. Anticarcinogenic and antimitotic effects of Turkish propolis and mitomycin-C on tissue cultures of bladder cancer. Nat Prod Res 2008; 22(12): 1060-1066.

15. Gunduz C, Biray C, Kosova B, Yilmaz B, Eroglu Z, Sahin F, Omay SB, Cogulu O.. Evaluation of Manisa propolis effect on leukemia cell line by telomerase activity. Leuk Res 2005; 29 (11): 1343-1346.

16. Chen YJ, Shiao MS, Hsu ML, Tsai TH, Wang SY. Effect of caffeic acid phenethyl ester, an antioxidant from propolis, on inducing apoptosis in human leukemic HL60 cells. J Agric Food Chem 2001; 49(11): 5615-5619.

17. Jin UH, Song KH, Motomura M, Suzuki I, Gu YH, Kang YJ, Moon TC, Kim CH. Cafeic acid phenethyl ester induces mitochondria-mediated apoptosis in human myeloid leukemia U937 cells. Mol Cell Biochem 2008; 310: 43-48.

18. Woo KJ, Jeong YJ, Park JW, Kwon TK. Chrysin-induced apoptosis is mediated through caspase activation and Akt inactivation in U937 leukemia cells. Biochem Biophys Res Commun 2004; 325: 1215-1222.

19. Chen CN, Wu CL, Lin JK. Apoptosis of human melanoma cells induced by the novel compounds propolin $A$ and propolin B from Taiwanese propolis. Cancer Lett 2007; 245: 218-231.

20. Chen CN, Wu CL, Lin JK. Propolin C from propolis induces apoptosis through activating caspases, Bid and cytochrome $c$ release in human melanoma cells. Biochem Pharmacol 2004; 67: 53-66.

21. Premratanachai $P$, Chanchao $C$. Review of the anticancer activities of bee products. Asian Pac J Trop Biomed 2014; 4(5): 337-344. 